\title{
The influence of different hormonal therapies on the reproductive, productive and economic efficiency of early postpartumdairy cows
}

\begin{abstract}
A total of 174 mutliparous Holstein dairy cows were randomly divided into seven groups to investigate the effects of different hormonal therapies on the productive, reproductive, and economic efficiency of early postpartum dairy cows. Our results show that cows treated with GnRH (gona dotropin-releasing hormone) had significantly $(\mathrm{P}<0.05)$ greater total milk yield than comparable untreated cows, and produced higher total and net returns. Reproductive parameters were also improved for the GnRH- treated cows. Additionally, we found that estrogen treatment has a positive impact on the productivity and profitability of cows receiving this treatment compared to control cows. In conclusion, GnRH and estrogen are the best hormonal therapies of those tested for improving the reproductive, productive, and economic efficiency of dairy cattle.
\end{abstract}

Keywords: hormonal therapy, reproductive, productive, economic, efficiency, dairy cattle
Volume I Issue 2 - 2014

\author{
Abdelgawad Salah El Tahawy,' Ali El Sharkawy² \\ 'Department of Animal Husbandry and Wealth development, \\ Daman hour University, Egypt \\ ${ }^{2}$ Faculty of Veterinary Medicine, Alexandria University, Egypt
}

\begin{abstract}
Correspondence: Abdelgawad Salah El Tahawy, Department of Animal Husbandry and Wealth development, Faculty of Veterinary Medicine, Daman hour University, Egypt, Tel 0100 II4
\end{abstract} 5631,Email abdelgawad.tahawy@vetmed.dmu.edu.eg

Received: September 15, 2014 | Published: November 12, 2014

\section{Introduction}

The reproductive status of a dairy herd has a large bearing on production profitability. Reproductive problems can result in excessively long lactation, long dry periods, or both, and are therefore costly to dairy producers. ${ }^{1}$ The main goals for postpartum reproductive health in dairy cattle are for the uterus to become completely involutes and free of infection, and for the cows to be cyclic by the time they enter the postpartum breeding period (after 50 to 60days lactation). The outcomes of good reproductive performance are the occurrence of pregnancy, normal time from calving to conception, and a reasonable number of inseminations. ${ }^{2}$

Foote and Rick ${ }^{3}$ reported that injection of GnRH (gonadotropinreleasing hormone) at 13 to 14 days postpartum helped cows undergoing slow involution of the reproductive system with no other clinical problems. It may also reduce the number ofdays to the first estrus without altering reproductive performance. ${ }^{4}$ Gaines $^{5}$ showed little or no positive impact on the subsequent fertility of cows treated with GnRH in the postpartum period. Furthermore, none of the following treatments administered to lactating dairy cows approximately 11 days postpartum sped up initiation of cyclic activity compared to control (saline-treated) cows: $500 \mu \mathrm{g} \mathrm{GnRH}, 10 \mathrm{mg}$ estradiol, $500 \mu \mathrm{g} \mathrm{GnRH}$ plus $10 \mathrm{mg}$ estradiol, or $500 \mu \mathrm{g}$ GnRH plus $10 \mathrm{mg}$ estradiol plus $25 \mathrm{mg}$ prostaglandin $(\mathrm{PG}) \mathrm{F} 2$ alpha.

Elsheikh and Elzubeir ${ }^{7}$ showed that double injection of PGF2 alpha during the first week, as well as a single ordouble injection of PGF2 alpha during the second or third week postpartum, minimized the days between calving and subsequent effective insemination, and accelerated the uterine involution. Therefore the use of PGF2 alphaduring the early postpartum period improved the reproductive efficiency of cross-bred dairy cows. The same authors reported that reproductive efficiency of cross-bred dairy cows was improved when PGF2 alpha was injectedduring the first three weeks postpartum.
Results obtained by Bajcsy et al. ${ }^{8}$ indicated that using 50IU of oxytocin intramuscularly enhances uterine contractility if treatment is given on the first day postpartum. Oxytocin administration immediately after delivery reduces the occurrence of retained fetal membranes in cattle, subsequently reducing the incidence of endometritis and improving the reproductive efficiency. ${ }^{9}$

Despite numerous studies investigating the effects of hormonal therapies immediately after parturition on reproductive parameters, there are few studies concerned with the effects on economic parameters of dairy cow production. Here, we evaluate the profitability of different drugs and drug combinations aimed at maximizing the productive, reproductive, and economic efficiency of dairy cattle farming.

\section{Materials and methods}

This study was carried out between August 2012 and August 2013 and aimed to evaluate the effects of some hormonal treatments on the reproductive performance of postpartum Holstein dairy cows.

\section{Animals and study area}

A total of 174 Holstein dairy cows of mixed parity belonging to a private farm about $80 \mathrm{~km}$ south of Alexandria were used in the present study. The cows were healthy and calved normally. Animals were grouped and fed according to milk yield, days in lactation, age, parity and body condition score. Cows were housed in open barns and provided with shelter, drinking water, and water mists during the summer season. The animals were fed concentrates consisting of $40 \%$ yellow corn, $13 \%$ wheat bran, $12 \%$ whole cotton seed, $30 \%$ soybean cakes and $5 \%$ minerals and vitamins, plus silage or berseem clover according to the season. The amount of feed depended on the production and parity. This diet was formulated to meet or exceed all National Research Council recommendations for lactating cows. ${ }^{10}$ The total mixed ration was placed in front of the cows five times 
perday for a total of 20 or more hours per day. Cows were milked three times daily (at $2 \mathrm{am}, 10 \mathrm{am}$ and $6 \mathrm{pm}$ ). The milk produced by each cow was recorded automatically through an electronic milk meter fixed to each milking unit in the parlor; the data were transported to a networked computer system that totalled the average milk yield per cow, perday, per week, per month and per lactation season (ALPRO herd management system, deLaval, Tumba, Sweden).

Cows were artificially inseminated $12 \mathrm{~h}$ after the onset of visible estrus; imported frozen semen from regularly tested sires that was provided by a variety of companies (ABS, WWS, Alta Genetics and Semex) was used to avoid inbreeding. Insemination data were collected from the farm, and reproductive performance information was found in thedairy record of the herd.

\section{Detection of estrus}

Estrus wasdetected by use of pedometer and observation twice daily, and confirmed by careful rectal palpation. The cows in estrus showed clinically normal genitalia and transparent estrus mucus without any turbidity or flacks, and were artificially inseminated toward to the end of estrus with good quality frozen semen.

\section{Pregnancy diagnosis}

The animals were rectally examined for pregnancydiagnosis at sixtydays post insemination.

\section{Treatments}

A total of 174 normally parturated Holstein cows were randomlydivided into seven groups:

i. Group 1 (GnRH-treated animals): Twenty-five normally parturateddairy cows were injected intramuscularly with $0.02 \mathrm{mg}$ of buserelin $(5 \mathrm{ml}$ Receptal, Intervet International B.V. Boxmeen, Holland) atday 14 postpartum.

ii. Group 2 (PGF2 alpha-treated animals): Twenty-two normally parturateddairy cows were injected intramuscularly with $25 \mathrm{mg}$ dinoprost (5ml Lutalyse, Pharmacia \& Upjhn Co, Kalamazoo, MI) immediately after calving (within two hours).

iii. Group 3 (Ergometrin-treated group): Nineteen normally parturateddairy cows were injected intramuscularly with $1 \mathrm{mg}$ methyl ergometrin hydrogen maleate $(5 \mathrm{ml}$ Methergin, Novartis Pharma S. A. E, Cairo under license from Novartis Pharma AG, Basel, Switzerland) immediately after parturition (within two hours).

iv. Group 4 (Oxytocin-treated group): Twenty-four normally parturateddairy cows were injected intramuscularly with 50IU oxytocin (5ml Oxytocin, ADWIA Co., 10th of Ramadan city, Egypt) immediately after calving (within two hours).

v. Group 5 (Estrogen-treated group): Twenty-one normally parturated cows were injected intramuscularly with $5 \mathrm{mg}$ estradiol benzoate (1 $\mathrm{ml}$ Folone, Misr Co. for Pharma. Ind, S.A.E) immediately after calving (within two hours).

vi. Group 6 (Estrogen followed by Oxytocin treated group): Eighteen normally parturated cows received $5 \mathrm{mg}$ estradiol benzoate at 12 hours after parturition followed by intramuscular injection with 50IU oxytocin six hours later.

vii. Group 7 (Non-treated group): Twenty normally parturated cowsdid not receive any treatment.

\section{Data collection}

Alldata collected including information concerningdate of parturition, veterinarydiagnosis and treatments, estrusdetection, inseminations and pregnancydiagnosis were entereddirectly into a computerdatabase.data entered included all management procedures in the form of cow cards; from those cow cards we obtained the following parameters which were used to measure reproductive performance in the herd;

\section{Parameters under investigation}

I. Days open: For cows that conceived,days open were calculated as thedays between calving and subsequent effective insemination. ${ }^{11}$

II. First service conception (S/C) rate (\%) and all service conception (SC) rate $(\%)$ : These rates weredefined as the percentage of inseminations that resulted in a confirmed pregnancy. ${ }^{12}$

III. Days to first insemination: This parameter measures thedays between calving and the first subsequent insemination.

IV. Total milk yield (kg): The actual amount of milk produced by each cow, either treated or untreated, throughout its calving interval.

V. Total fixed costs: The total fixed costs ofdairy production included thedepreciation of buildings, animals, equipment, and thedairy parlor. Thedepreciation rates were calculated for the building anddairy parlor bydividing the estimated sale price of the building by 25 or 15 years, respectively. The animaldepreciation was calculated by subtracting the value of the animal as meat from the purchase value anddividing by 13 , which represented the estimated production lifetime of the animal in years, according to the fixed line method of Sankhayan. ${ }^{13}$

VI. Total costs: Total costs included the actual costs of feed, veterinary visits, labour, insemination (one straw costs 75 EGP), and treatment. Total costs were calculated throughout the calving interval of both treated and untreated cows. The calving interval was included as a factor in the comparison of the total costs ofdiseased and healthy cows. ${ }^{14}$ The extended calving intervals ofdiseased cows required greater feed, labour and total veterinary management costs when compared to healthy cows.

VII. Total returns: Total returns reflect the summation of milk returns and calf returns. Milk returns were calculated as the price of 1 $\mathrm{kg}$ of milk (EGP) multiplied by the total milk yield produced by the cow throughout its calving interval. Calf returns were calculated as the value of each calf sold (EGP).

VIII. Net return: Net return was calculated as thedifference between total returns and total costs.

\section{Statistical analysis}

Productivity (days lactating and total milk yield), cost (insemination, veterinary visits, treatment, and total costs), and returns (total returns and net return) were compared acrossdifferent treatment groups indifferent experiments. The statistical model included the effect of treatment and lactation order. Non-significant treatment by lactation order interactions were removed from the final model. Each treatment was analysed separately by a general linear model. All analyses were performed using the Statistical Analysis System computer package. ${ }^{15}$ 
The following statistical model was applied:

$$
\mathrm{Yij}=\mu+\mathrm{Ti}+\mathrm{eij}
$$

Where Yij: observed value, $\mu$ : overall mean, Ti: treatment effect, eij: unexplained error term.

Cox's proportional hazard analysis was performed using the PHREG procedure in SAS to examine the effect of treatment on the hazard ratio of pregnancy. Dummy variables were created for the treatment and control groups. A crude estimate of the effect of treatment on median days to first service and median days open was determined by Kaplan-Meier survival analysis (LIFETEST procedure). First-service conception rates and all-service conception rates were analysed using the Chi-squared test.

\section{Results}

\section{GnRH-treatment}

Table 1 shows the effects of GnRH treatment on the relative pregnancy rates of all cows. When all cows were considered and the diagnostic categories were excluded, the relative pregnancy rate of cows receiving treatment was higher than that of control cows. Treatment with GnRH increased the pregnancy rate by $73 \%$ relative to control cows.

The reproductive, productive, and costs parameters are presented in Table 2. The median number of days to first insemination or days open for the control group was greater $(90$ and $180 \mathrm{~d}$; $\mathrm{P}<0.05)$ than that for cows receiving $\mathrm{GnRH}$ treatment (76 and 153d, respectively). The first S/C and all S/C rates for cows treated with $\mathrm{GnRH}$ showed greater values ( 58 and $96 \% ; \mathrm{P}<0.05$ ) than for untreated cows (33 and $84 \%$, respectively).

Measurements of productivity (milk production and days in milk) are depicted in Table 2. GnRH-treated cows remained in lactation for significantly shorter periods $(349.54 \mathrm{~d} ; \mathrm{P}<0.05)$ than untreated cows (385.08d). Even with longer lactation periods, untreated control cows had a smaller total milk yield $(10663.20 \mathrm{~kg} ; \mathrm{P}<0.05)$ than those treated with GnRH (11756.30kg).

The insemination cost for cows receiving $\mathrm{GnRH}$ was significantly less $(132.45 \mathrm{EGP} ; \mathrm{P}<0.05)$ than that for untreated cows (185.32EGP). Veterinary visit costs as well as total fixed costs were the same for both groups. However, feed and total costs were significantly $(\mathrm{P}<0.05)$ less for cows treated with GnRH than those for the control group. The feed costs were 15220.12EGP for GnRH-treated cows and 13190.45EGP for control cows. Consequently, the total costs for GnRH-treated cows were significantly lower $(15355.90 \mathrm{EGP} ; \mathrm{P}<0.05)$ than those for untreated cows (17260.44EGP).

As shown in Table 3, returns parameters were represented by milk returns, calf sales, total returns, and net return. Cows treated with $\mathrm{GnRH}$ showed significantly $(\mathrm{P}<0.05)$ higher milk returns (23512.60EGP) than untreated cows (21326.40EGP). Therefore, the total returns for cows receiving GnRH were significantly $(\mathrm{P}<0.05)$ greater (25512.60EGP) than those for the control group (23326.40 EGP).due to higher total returns and lower total costs for cows treated with GnRH, the net profit of this group was significantly greater $(8156.70 \mathrm{EGP}, \mathrm{P}<0.05)$ than the net profit of the control group (4065.96EGP).

Table I Effect of postpartum gonadotropin releasing hormone injection on the relative rate of pregnancy

\begin{tabular}{llll}
\hline Criteria & HRPa & $\mathbf{9 5 \%} \mathbf{C l}$ & Probability \\
\hline Control & & & 0.04 \\
GnRH & 1.73 & $1.21-2.89$ & 0.05
\end{tabular}

${ }^{a}$ Hazard ratio of pregnancy

Table 2 Reproductive, productive, and costs parameters of $\mathrm{GnRH}$-treated groups and those controls

\begin{tabular}{|c|c|c|c|c|c|c|c|c|c|c|c|}
\hline Criteria & $\begin{array}{l}\text { MDI } \\
(\mathrm{Cl})^{\mathrm{B}}\end{array}$ & $\begin{array}{l}\text { MDO } \\
(\mathrm{Cl})^{\mathrm{B}}\end{array}$ & $\begin{array}{l}I^{\text {st }} / \mathbf{C} \\
(\%)^{A}\end{array}$ & $\begin{array}{l}\text { All S/C } \\
\text { rates } \\
(\%)^{\mathrm{A}}\end{array}$ & DIM(days) & TMY(Kg) & $\begin{array}{l}\text { Insemination } \\
\text { cost(EGP) }\end{array}$ & VS & $\begin{array}{l}\text { Feed } \\
\operatorname{cost}(E G P)\end{array}$ & TFC(EGP) & TC(EGP) \\
\hline Control & $\begin{array}{l}90(80 \\
110) \mathrm{a}\end{array}$ & $\begin{array}{l}\text { 180(170, } \\
195) \text { a }\end{array}$ & $33 b$ & $84 b$ & $\begin{array}{l}385.08 \pm \\
9.69 \mathrm{a}\end{array}$ & $\begin{array}{l}10663.20 \pm \\
85.09 \mathrm{~b}\end{array}$ & $185.32 \pm 8.12 \mathrm{a}$ & 100 & $\begin{array}{l}15220.12 \pm \\
116.24 \mathrm{a}\end{array}$ & $1855 \pm 56.25$ & $\begin{array}{l}17260.44 \pm \\
113.33 a\end{array}$ \\
\hline GnRH & $\begin{array}{l}76(70 \\
85) \mathrm{b}\end{array}$ & $\begin{array}{l}\text { I53(140, } \\
168) \mathrm{b}\end{array}$ & $58 \mathrm{a}$ & $96 a$ & $\begin{array}{l}349.54 \pm \\
9.74 b\end{array}$ & $\begin{array}{l}11756.30 \pm \\
74.43 a\end{array}$ & $132.45 \pm 7.13 b$ & 100 & $\begin{array}{l}13190.45 \pm \\
120.07 b\end{array}$ & $1855 \pm 56.13$ & $\begin{array}{l}15355.90 \pm \\
109.38 \mathrm{~b}\end{array}$ \\
\hline
\end{tabular}

Means within the same column carrying different letters are significantly different $(P<0.05)$

Means are expressed as LSM(least squares means) $\pm S E$ (standard error).

Achi-square test

BLIFETEST procedure

MDI, median days to first insemination; MDO, median days open; DIM=Days In Milk (lactation period); TMY=total milk yield; VS=veterinary visits;TFC=total fixed costs; $\mathrm{TC}=$ total costs; $\mathrm{EGP}=$ egyptian pound

Table 3 Returns parameters of GnRH-treated group and those untreated

\begin{tabular}{lllll}
\hline Criteria & Milk returns(EGP) & Calf returns(EGP) & Total returns (EGP) & Net return(EGP) \\
\hline Control & $21326.40 \pm 143.26 \mathrm{~b}$ & 2000 & $23326.40 \pm 147.26 \mathrm{~b}$ & $4065.96 \pm 189.35 \mathrm{~b}$ \\
GnRH & $23512.60 \pm 156.28 \mathrm{a}$ & 2000 & $25512.60 \pm 156.28 \mathrm{a}$ & $8156.70 \pm 176.47 \mathrm{a}$ \\
\hline
\end{tabular}

Means within the same column carrying different letters are significantly different $(P<0.05)$ 


\section{Prostaglandin F2 alpha treatment}

Table 4 shows that PGF2 alpha increased pregnancy rates by $66 \%$ relative to the control. The median days to first insemination, median days open, and the first $\mathrm{S} / \mathrm{C}$ rates were not significantly different between the treated and control groups (Table 5). However, all S/C rates of the untreated group were significantly $(\mathrm{P}<0.05)$ higher $(84 \%)$ than those of the treated group $(72 \%)$. The productive parameters represented by total milk yield and days in milk are shown in Table 5.days in milk were not significantly different between the treated and untreated groups. In contrast, the total milk yield of the untreated cows was significantly $(\mathrm{P}<0.05)$ greater $(10663.20 \mathrm{~kg})$ than that of cows treated with PGF2 alpha $(8869.90 \mathrm{~kg})$. The insemination costs of the control cows were not significantly different (185.32EGP; $\mathrm{P}>0.05$ ) when compared to the treated cows (190.45EGP).

Feed costs of the control cows were higher $(15220.12 \mathrm{EGP} ; \mathrm{P}<0.05)$ than those of treated cows (14879.23EGP). Total fixed costs were the same for both groups and total costs were not significantly different (17260.44EGP for control cows and 17024.68EGP for treated cows).

Table 6 shows the returns from milk and calf sales and the net return obtained. Milk returns for untreated cows were significantly $(\mathrm{P}<0.05)$ greater $(21326.40 \mathrm{EGP})$ than for cows treated with PGF2 alpha (17739.80EGP). Similarly, the total returns for the control cows were significantly greater than for the treated cows (23326.40EGP vs. 19739.80EGP; $\mathrm{P}<0.05$ ), as were the net returns (4065.95EGP vs. 2715.12EGP; $\mathrm{P}<0.05)$.

Table 4 Effect of postpartum prostaglandin F2 alpha injection on the relative rate of pregnancy

\begin{tabular}{lccl}
\hline Criteria & HRPa & $\mathbf{9 5 \%} \mathbf{C l}$ & Probability \\
\hline Control & & & 0.04 \\
Prostaglandin F2 alpha & 1.66 & $\mathrm{I} .1 \mathrm{I}-2.38$ & 0.01 \\
\hline
\end{tabular}

${ }^{a}$ Hazard ratio of pregnancy

\section{Ergometrin treatment}

As presented in Table 7, ergometrin increased the pregnancy rates by $54 \%$ relative to control. Reproductive parameters are shown in Table 8. The median days to first service for control cows was significantly higher $(\mathrm{P}<0.05)$ than for those treated with ergometrin. Nevertheless, median days open of ergometrin-treated cows was greater $(\mathrm{P}<0.05)$ than of control cows. The first $\mathrm{S} / \mathrm{C}$ and all $\mathrm{S} / \mathrm{C}$ rates for the control cows were significantly higher than for those receiving ergometrin treatments ( 33 and $84 \%$ vs. 7 and 57\%, respectively).

Table 5 Effect of prostaglandin F2 alpha administration immediately after calving on fertility, productive, and costs parameters of dairy cows

\begin{tabular}{|c|c|c|c|c|c|c|c|c|c|c|c|}
\hline Criteria & $\operatorname{MDI}(\mathrm{Cl})^{\mathrm{B}}$ & $\operatorname{MDO}(\mathrm{CI})^{\mathrm{B}}$ & $\begin{array}{l}\text { I }^{\text {st }} / \mathbf{C} \\
(\%)^{A}\end{array}$ & $\begin{array}{l}\text { All } \\
\text { S/C } \\
\text { rates } \\
(\%)^{A}\end{array}$ & $\begin{array}{l}\text { DIM } \\
\text { (days) }\end{array}$ & TMY(Kg) & $\begin{array}{l}\text { Insemination } \\
\text { cost(EGP) }\end{array}$ & VS & $\begin{array}{l}\text { Feed } \\
\text { cost } \\
\text { (EGP) }\end{array}$ & $\begin{array}{l}\text { TFC } \\
\text { (EGP) }\end{array}$ & $\begin{array}{l}\text { TC } \\
\text { (EGP) }\end{array}$ \\
\hline Control & $90(80, I I 0) a$ & $180(\mid 70,195) a$ & $33 a$ & $84 a$ & $\begin{array}{l}385.08 \pm \\
9.69 a\end{array}$ & $\begin{array}{l}10663.2 \pm \\
85.09 \mathrm{a}\end{array}$ & $\begin{array}{l}185.32 \pm \\
8.12 a\end{array}$ & 100 & $\begin{array}{l}15220.12 \pm \\
116.24 a\end{array}$ & $\begin{array}{l}1855 \pm \\
56.25 a\end{array}$ & $\begin{array}{l}\text { I } 7260.44 \pm \\
113.33 \mathrm{a}\end{array}$ \\
\hline $\begin{array}{l}\text { Prostaglandin } \\
\text { F2 alpha }\end{array}$ & $90(80,125) a$ & I74(162, I87)a & $33 a$ & $72 B$ & $\begin{array}{l}375.59 \pm \\
12.93 a\end{array}$ & $\begin{array}{l}8869.90 \pm \\
56.43 \mathrm{~B}\end{array}$ & $\begin{array}{l}190.45 \pm \\
8.12 a\end{array}$ & 100 & $\begin{array}{l}14879.23 \pm \\
118.12 B\end{array}$ & $\begin{array}{l}1855 \pm \\
56.25 a\end{array}$ & $\begin{array}{l}17024.68 \pm \\
114.56 a\end{array}$ \\
\hline
\end{tabular}

Means within the same column carrying different letters are significantly different $(P<0.05)$

Table 6 Returns parameters of prostaglandin F2 alpha-treated group and those untreated

\begin{tabular}{lcccc}
\hline Criteria & Milk returns(EGP) & Calf returns(EGP) & Total returns(EGP) & Net return(EGP) \\
\hline Control & $21326.40 \pm \mid 43.26 \mathrm{a}$ & 2000 & $23326.40 \pm \mid 47.26 \mathrm{a}$ & $4065.96 \pm 189.35 \mathrm{a}$ \\
Prostaglandin F2 alpha & $17739.80 \pm \mid 65.28 \mathrm{~B}$ & 2000 & $19739.80 \pm \mid 65.28 \mathrm{~B}$ & $27 \mid 5.12 \pm 194.47 \mathrm{~B}$
\end{tabular}

Means within the same column carrying different letters are significantly different $(P<0.05)$

Table 7 Effect of postpartum ergometrin injection on the relative rate of pregnancy

\begin{tabular}{llll}
\hline Criteria & HRPa & $\mathbf{9 5 \%} \mathbf{C l}$ & Probability \\
\hline Control & & & 0.04 \\
Ergometrin & 1.54 & $1.13-3.16$ & 0.01 \\
\hline
\end{tabular}

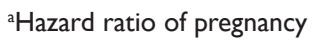


Milk yield of both treated and untreated cows throughout their lactation period is presented in Table 8 . Total milk yield of the cows treated with ergometrin over their lactation period (420.78d) was significantly lower $(8213.60 \mathrm{~kg} ; \mathrm{P}<0.05)$ than that of control cows (10663.20kg; 385.08d lactation).Insemination costs for the cows treated with ergometrin were significantly greater than for untreated cows (225.46 EGP vs. 185.32 EGP, respectively). Veterinary visits and total fixed costs were the same for both treated and untreated cows. Feed costs and total costs were significantly less for cows treated with ergometrin than for those untreated (Table 8). Feed costs for control cows were 15220.12EGP and for ergometrin-treated cows were 15023.22 EGP. Subsequently, total costs for the untreated cows were significantly $(\mathrm{P}<0.05 ; 17203.68 \mathrm{EGP})$ less than for comparable treated group (17260.44EGP).

Regarding the returns parameters (Table 9), ergometrin treatment had no positive effect on the total returns. Milk and total returns for the control cows were significantly $(\mathrm{P}<0.05)$ greater (21326.40EGP and 23326.40EGP, respectively) than for those receiving ergometrin treatment (16427.20EGP and 18427.20EGP, respectively). Accordingly, the net return for the control cows was greater $(4065.96 \mathrm{EGP}, \mathrm{P}<0.05)$ than that for ergometrin-treated cows (1223.52EGP).

\section{Oxytocin-treatment}

As shown in Table 10, oxytocin increased the relative rate of pregnancy by $70 \%$ relative to control. According to Table 11 , median days to first insemination was significantly higher for the control group than for cows treated with oxytocin (90d vs. 77; $\mathrm{P}<0.05$ ). Median days open for oxytocin-treated cows was not significantly different compared to control cows. The first $\mathrm{S} / \mathrm{C}$ and all $\mathrm{S} / \mathrm{C}$ rates for untreated cows were significantly greater compared to treated group ( $\mathrm{P}<0.05 ; 33 \%$ and $84 \%$ vs. $25 \%$ and $68 \%$, respectively).

Productivity in terms of milk yield for both treated and untreated cows throughout their lactation period is presented in Table 11. Oxytocin-treated cows yielded less milk than untreated cows $(\mathrm{P}<0.05$; $8968.3 \mathrm{~kg}$ and $447.52 \mathrm{~d}$ vs. $10663.20 \mathrm{~kg}$ and $385.08 \mathrm{~d}$, respectively). Regarding costs parameters, feed costs of the control cows were significantly lower $(\mathrm{P}<0.05 ; 15220.12 \mathrm{EGP})$ than of those receiving oxytocin treatment (16011.54EGP). Therefore, total costs for the cows treated with oxytocin were significantly greater $(\mathrm{P}<0.05$; 18231.99EGP) than for untreated cows (17260.44 EGP).

Veterinary visits and total fixed costs were the same for both treated and untreated groups. Profitability measures are presented in Table 12. Milk returns for control cows were significantly greater $(\mathrm{P}<0.05$; 21326.40EGP) than for those treated with oxytocin (17936.60EGP). For that reason, total returns for untreated cows were higher $(\mathrm{P}<0.05$; 23326.40EGP) than those for oxytocin-treated cows (19936.60EGP). Net return for the group receiving oxytocin was significantly lower $(\mathrm{P}<0.05 ; 1704.61 \mathrm{EGP})$ than that for the control group (4065.96EGP).

Table 8 Effect of ergometrin treatment after calving on fertility, productive, and costs parameters of dairy cows

\begin{tabular}{|c|c|c|c|c|c|c|c|c|c|c|c|}
\hline Criteria & $\begin{array}{l}\text { MDI } \\
(\mathrm{Cl})^{\mathrm{B}}\end{array}$ & $\begin{array}{l}\text { MDO } \\
(\mathrm{Cl})^{\mathrm{B}}\end{array}$ & $\begin{array}{l}I^{\text {st }} / \mathbf{C} \\
(\%)^{A}\end{array}$ & $\begin{array}{l}\text { All } \\
\text { S/C } \\
\text { rates } \\
(\%)^{\mathbf{A}}\end{array}$ & DIM(days) & TMY(Kg) & $\begin{array}{l}\text { Insemination } \\
\text { cost(EGP) }\end{array}$ & VS & $\begin{array}{l}\text { Feed } \\
\operatorname{cost}(E G P)\end{array}$ & TFC(EGP) & TC(EGP) \\
\hline Control & $\begin{array}{l}90(80 \\
110) a\end{array}$ & $\begin{array}{l}180(170 \\
195) \mathrm{B}\end{array}$ & $33 a$ & $84 a$ & $\begin{array}{l}385.08 \pm \\
9.69 \mathrm{~B}\end{array}$ & $\begin{array}{l}10663.20 \pm \\
85.09 a\end{array}$ & $185.32 \pm 8.12 B$ & 100 & $\begin{array}{l}15220.12 \pm \\
116.24 \mathrm{a}\end{array}$ & $1855 \pm 56.25 a$ & $\begin{array}{l}17260.44 \pm \\
113.33 \mathrm{a}\end{array}$ \\
\hline Ergometrin & $\begin{array}{l}78(68 \\
95) \mathrm{B}\end{array}$ & $\begin{array}{l}249(235 \\
263) \mathrm{a}\end{array}$ & $7 B$ & $57 \mathrm{~B}$ & $\begin{array}{l}420.78 \pm \\
11.44 a\end{array}$ & $\begin{array}{l}8213.60 \pm \\
67.43 \mathrm{~B}\end{array}$ & $225.46 \pm 9.7 a$ & 100 & $\begin{array}{l}15023.22 \pm \\
135.12 B\end{array}$ & $1855 \pm 56.25 \mathrm{a}$ & $\begin{array}{l}17203.68 \pm \\
134.56 a\end{array}$ \\
\hline
\end{tabular}

Means within the same column carrying different letters are significantly different $(P<0.05)$

Table 9 Returns parameters of ergometrin-treated group and those untreated

\begin{tabular}{lllll}
\hline Criteria & Milk returns(EGP) & Calf returns(EGP) & Total returns(EGP) & Net return(EGP) \\
\hline Control & $21326.40 \pm \mid 43.26 \mathrm{a}$ & 2000 & $23326.40 \pm 143.26 \mathrm{a}$ & $4065.96 \pm 189.35 \mathrm{a}$ \\
Ergometrin & $16427.20 \pm \mid 68.2 \mathrm{IB}$ & 2000 & $18427.20 \pm \mid 68.21 \mathrm{~B}$ & $1223.52 \pm \mid 59.14 \mathrm{~B}$
\end{tabular}

Means within the same column carrying different letters are significantly different $(P<0.05)$

Table 10 Effect of postpartum oxytocin hormone injection on the relative rate of pregnancy

\begin{tabular}{llll}
\hline Criteria & HRP $^{\mathbf{a}}$ & $\mathbf{9 5 \%} \mathbf{C l}$ & Probability \\
\hline Control & & & 0.04 \\
Oxytocin & 1.7 & $1.00-2.88$ & 0.05 \\
\hline
\end{tabular}

${ }^{a}$ Hazard ratio of pregnancy 
Table I I Effect of oxytocin treatment immediately after calving on fertility, productive, and costs parameters of dairy cows

\begin{tabular}{|c|c|c|c|c|c|c|c|c|c|c|c|}
\hline Criteria & $\begin{array}{l}\text { MDI } \\
(\mathrm{Cl})^{\mathrm{B}}\end{array}$ & $\begin{array}{l}\text { MDO } \\
(\mathrm{Cl})^{\mathrm{B}}\end{array}$ & $\begin{array}{l}\text { I }^{\text {st }} \text { /C } \\
(\%)^{A}\end{array}$ & $\begin{array}{l}\text { All } \\
\text { S/C } \\
\text { rates } \\
(\%)^{A}\end{array}$ & DIM(days) & TMY(Kg) & $\begin{array}{l}\text { Insemination } \\
\text { cost(EGP) }\end{array}$ & VS & $\begin{array}{l}\text { Feed } \\
\operatorname{cost}(E G P)\end{array}$ & TFC(EGP) & TC(EGP) \\
\hline Control & $\begin{array}{l}90(80 \\
110) a\end{array}$ & $\begin{array}{l}180(170 \\
195) a\end{array}$ & $33 a$ & $84 a$ & $\begin{array}{l}385.08 \pm \\
9.69 \mathrm{~B}\end{array}$ & $\begin{array}{l}10663.2 \pm \\
85.09 a\end{array}$ & $185.32 \pm 8.12 B$ & 100 & $\begin{array}{l}15220.12 \pm \\
116.24 a\end{array}$ & $1855 \pm 56.25 a$ & $\begin{array}{l}\text { I } 7260.44 \pm \\
\text { II } 3.33 \mathrm{a}\end{array}$ \\
\hline Oxytocin & $\begin{array}{l}77(65, \\
83) B\end{array}$ & $\begin{array}{l}184(175 \\
198) a\end{array}$ & $25 B$ & $68 \mathrm{~B}$ & $\begin{array}{l}447.52 \pm \\
12.35 \mathrm{a}\end{array}$ & $\begin{array}{l}8968.3 \pm \\
82.22 B\end{array}$ & $265.45 \pm 13.45 a$ & 100 & $\begin{array}{l}16011.54 \pm \\
135.12 B\end{array}$ & $1855 \pm 56.25 a$ & $\begin{array}{l}18231.99 \pm \\
129.12 \mathrm{a}\end{array}$ \\
\hline
\end{tabular}

Means within the same column carrying different letters are significantly different $(P<0.05)$

Table I 2 Returns parameters of oxytocin-treated group and those untreated

\begin{tabular}{lllll}
\hline Criteria & Milk returns(EGP) & Calf returns(EGP) & Total returns(EGP) & Net return(EGP) \\
\hline Control & $21326.40 \pm \mid 43.26 \mathrm{a}$ & 2000 & $23326.40 \pm 147.26 \mathrm{~B}$ & $4065.96 \pm 189.35 \mathrm{a}$ \\
Oxytocin & $17936.60 \pm \mid 89.47 \mathrm{~B}$ & 2000 & $19936.60 \pm 189.47 \mathrm{~B}$ & $1704.61 \pm 193.45 \mathrm{~B}$ \\
\hline
\end{tabular}

Means within the same column carrying different letters are significantly different $(P<0.05)$

\section{Estrogen-treatment}

According to Table 13, the rate of pregnancy was greater relative to control when cows were treated with estrogen $(86 \%)$. Reproductive performance was significantly improved by estrogen treatment. Median days to first insemination and median days open were significantly improved (64d and $102 \mathrm{~d}$ vs. $90 \mathrm{~d}$ and $180 \mathrm{~d}$, respectively) for cows treated with estrogen compared to control cows. Moreover, the first $\mathrm{S} / \mathrm{C}$ and all $\mathrm{S} / \mathrm{C}$ rates for control cows were significantly less than for those treated with estrogen (33\% and $84 \%$ vs. 53 and $94 \%$, respectively).

Table I 3 Effect of postpartum estrogen hormone injection on the relative rate of pregnancy

\begin{tabular}{llll}
\hline Criteria & HRPa & $\mathbf{9 5 \%} \mathbf{C l}$ & Probability \\
\hline Control & & & 0.04 \\
estrogen & 1.86 & $1.00-3.12$ & 0.01 \\
\hline
\end{tabular}

${ }^{\text {aHazard }}$ ratio of pregnancy

Milk yield of the estrogen-treated cows over their lactation period was higher than for control cows $(11337.70 \mathrm{~kg}$ over $353.78 \mathrm{~d}$ vs. $10663.20 \mathrm{~kg}$ over $385.08 \mathrm{~d})$. Insemination costs of the control cows were greater than of those receiving estrogen (185.32EGP vs. 178.45EGP), but this difference was not significant. Feed costs of the untreated cows were significantly greater than of estrogen-treated cows $(15220.12 \mathrm{EGP}$ vs. $14986.56 \mathrm{EGP} ; \mathrm{P}<0.05)$. Veterinary visits, total fixed costs, and total costs were the same for both treated and untreated cows (Table 14).

Table 15 shows the returns parameters of both treated and untreated cows. Milk returns from estrogen-treated cows were significantly greater than those from control cows (22675.40EGP vs. 21326.40EGP; $\mathrm{P}<0.05)$. Total returns follow the same trend. In addition, net profit of the estrogen-treated cows was significantly higher $(\mathrm{P}<0.05$; 7555.30EGP) than that of untreated cows (4065.96EGP) (Table 15).

The reproductive parameters of the cows injected with estrogen followed by oxytocin were significantly improved. The rate of pregnancy was $74 \%$ relative to control (Table 16). However, as shown in Table 17, mediandays to first insemination and median days open were significantly greater for treated cows than for untreated cows (174d and $258 \mathrm{~d}$ vs. $90 \mathrm{~d}$ and $18 \mathrm{~d}$, respectively; $\mathrm{P}<0.05$ ). First $\mathrm{S} / \mathrm{C}$ and all $\mathrm{S} / \mathrm{C}$ rates of untreated cows were significantly higher than of those treated with estrogen-oxytocin combination (33\% and $100 \%$ vs. $15 \%$ and $69 \%$, respectively; $\mathrm{P}<0.05$ ). Productivity of control cows was higher than of treated cows. Total milk yield of the control cows was significantly higher than of treated cows over their lactation periods $(10663.20 \mathrm{~kg}$ and $385.08 \mathrm{~d}$ vs. $8743.90 \mathrm{~kg}$ and $423.78 \mathrm{~d}$, respectively; $\mathrm{P}<0.05)$. Insemination costs of the estrogen-oxytocin treatment were significantly higher than of the control (225.69EGP vs. 185.32EGP).

Table 14 Effect of administration of estrogen immediately after parturition on fertility, productive, and costs parameters of dairy cows

\begin{tabular}{|c|c|c|c|c|c|c|c|c|c|c|c|}
\hline Criteria & $\begin{array}{l}\text { MDI } \\
(\mathrm{CI})^{\mathrm{B}}\end{array}$ & $\begin{array}{l}\text { MDO } \\
(\mathrm{CI})^{\mathrm{B}}\end{array}$ & $\begin{array}{l}\left.\right|^{\text {st }} \mathbf{S} / \mathbf{C} \\
(\%)^{A}\end{array}$ & $\begin{array}{l}\text { All } \\
\text { S/C } \\
\text { rates } \\
(\%)^{A}\end{array}$ & DIM(days) & TMY(Kg) & $\begin{array}{l}\text { Insemination } \\
\text { cost(EGP) }\end{array}$ & VS & $\begin{array}{l}\text { Feed } \\
\text { cost(EGP) }\end{array}$ & $\begin{array}{l}\text { TFC } \\
\text { (EGP) }\end{array}$ & TC(EGP) \\
\hline Control & $\begin{array}{l}90(80 \\
110) a\end{array}$ & $\begin{array}{l}180(170 \\
195) \mathrm{a}\end{array}$ & $33 B$ & $84 B$ & $\begin{array}{l}385.08 \pm \\
9.69 a\end{array}$ & $\begin{array}{l}10663.2 \pm \\
85.09 B\end{array}$ & $185.32 \pm 8.12 \mathrm{a}$ & 100 & $\begin{array}{l}15220.12 \pm \\
116.24 \mathrm{a}\end{array}$ & $\begin{array}{l}1855 \pm \\
56.25 \mathrm{a}\end{array}$ & $\begin{array}{l}\text { I } 7260.44 \pm \\
113.33 a\end{array}$ \\
\hline Estrogen & $\begin{array}{l}64(52 \\
78) B\end{array}$ & $\begin{array}{l}102(87 \\
119) \mathrm{B}\end{array}$ & $53 a$ & $94 a$ & $\begin{array}{l}353.78 \pm \\
8.35 B\end{array}$ & $\begin{array}{l}11337.7 \pm \\
54.43 a\end{array}$ & $178.45 \pm 10.45 a$ & 100 & $\begin{array}{l}14986.56 \pm \\
144.12 B\end{array}$ & $\begin{array}{l}1855 \pm \\
56.25 a\end{array}$ & $\begin{array}{l}17120.10 \pm \\
139.12 \mathrm{a}\end{array}$ \\
\hline
\end{tabular}

Means within the same column carrying different letters are significantly different $(P<0.05)$ 
Table I 5 Returns parameters of estrogen-treated group and those untreated

\begin{tabular}{lllll}
\hline Criteria & Milk returns(EGP) & Calf returns(EGP) & Total returns(EGP) & Net return(EGP) \\
\hline Control & $21326.40 \pm \mid 47.26 \mathrm{~B}$ & 2000 & $23326.40 \pm \mid 47.26 \mathrm{~B}$ & $4065.96 \pm \mid 89.35 \mathrm{~B}$ \\
Estrogen & $22675.40 \pm \mid 34.50 \mathrm{a}$ & 2000 & $24675.40 \pm \mid \mathrm{3} 4.50 \mathrm{a}$ & $7555.30 \pm 135.16 \mathrm{a}$ \\
\hline
\end{tabular}

Means within the same column carrying different letters are significantly different $(P<0.05)$

As presented in Table 17, feed costs and total costs of the estrogenoxytocin treatment group were significantly greater than of untreated cows (15945.23EGP and 18125.92EGP vs. 15220.12EGP and 17260.44EGP; $\mathrm{P}<0.05)$.

Table 18 shows the returns parameters of both treated and untreated cows. Milk returns for untreated cows were higher than for treated cows (21326.40 EGP vs. 17487.80 EGP; $\mathrm{P}<0.05$ ). Total returns show the same trend. As a result of higher total returns and lower total costs for the control cows, the net return was considerably higher than for treated cows (4065.96 EGP vs. 1361.88 EGP; $\mathrm{P}<0.05$ ).
Table 16 Effect of postpartum estrogen followed by oxytocin injection on the relative rate of pregnancy

\begin{tabular}{llll}
\hline Criteria & HRPa & $95 \% \mathrm{Cl}$ & Probability \\
\hline Control & & & 0.04 \\
Estrogen-oxytocin & 1.74 & $1.16-2.23$ & 0.04 \\
\hline
\end{tabular}

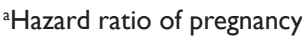

Table 17 Effect of estrogen treatment followed by oxytocin on fertility, productive, and costs parameters of postpartum dairy cows

\begin{tabular}{|c|c|c|c|c|c|c|c|c|c|c|c|}
\hline Criteria & $\begin{array}{l}\text { MDI } \\
(\mathrm{Cl})^{\mathrm{B}}\end{array}$ & $\begin{array}{l}\text { MDO } \\
(\mathrm{Cl})^{\mathrm{B}}\end{array}$ & $\begin{array}{l}I^{\text {st }} / \mathbf{C} \\
(\%)^{A}\end{array}$ & $\begin{array}{l}\text { All } \\
\text { S/C } \\
\text { rates } \\
(\%)^{A}\end{array}$ & DIM(days) & TMY(Kg) & $\begin{array}{l}\text { Insemination } \\
\text { cost(EGP) }\end{array}$ & VS & $\begin{array}{l}\text { Feed } \\
\operatorname{cost}(E G P)\end{array}$ & $\begin{array}{l}\text { TFC } \\
\text { (EGP) }\end{array}$ & TC(EGP) \\
\hline Control & $\begin{array}{l}90(80 \\
110) B\end{array}$ & $\begin{array}{l}180(170 \\
195) \text { B }\end{array}$ & $33 a$ & $100 \mathrm{a}$ & $\begin{array}{l}385.08 \pm \\
9.69 \mathrm{~B}\end{array}$ & $\begin{array}{l}10663.2 \pm \\
85.09 a\end{array}$ & $185.32 \pm 8.12 B$ & 100 & $\begin{array}{l}15220.12 \pm \\
116.24 \mathrm{~B}\end{array}$ & $\begin{array}{l}1855 \pm \\
56.25 \mathrm{a}\end{array}$ & $\begin{array}{l}17260.44 \pm \\
113.33 B\end{array}$ \\
\hline $\begin{array}{l}\text { Estrogen- } \\
\text { oxytocin }\end{array}$ & $\begin{array}{l}174(160 \\
183) \mathrm{a}\end{array}$ & $\begin{array}{l}258(223 \\
274) \text { a }\end{array}$ & I5B & $69 B$ & $\begin{array}{l}423.78 \pm \\
5.54 \mathrm{a}\end{array}$ & $\begin{array}{l}8743.90 \pm \\
64.23 \mathrm{~B}\end{array}$ & $225.69 \pm 9.23 a$ & 100 & $\begin{array}{l}15945.23 \pm \\
144.12 a\end{array}$ & $\begin{array}{l}1855 \pm \\
56.25 \mathrm{a}\end{array}$ & $\begin{array}{l}18125.92 \pm \\
139.12 a\end{array}$ \\
\hline
\end{tabular}

Means within the same column carrying different letters are significantly different $(P<0.05)$

Table I 8 Returns parameters of estrogen-oxytocin treated group and those untreated

\begin{tabular}{llll}
\hline Criteria & Milk returns(EGP) & Calf returns(EGP) & Total returns(EGP) \\
\hline Control & $2|326.40 \pm| 47.26 \mathrm{~B}$ & 2000 & $23326.40 \pm \mid 47.26 \mathrm{a}$ \\
Estrogen-oxytocin & $17487.80 \pm \mid 64.45 \mathrm{a}$ & 2000 & $19487.80 \pm \mid 64.45 \mathrm{~B}$ \\
\hline
\end{tabular}

Means within the same column carrying different letters are significantly different $(P<0.05)$

\section{Discussion}

Wedescribed the effects of various hormonal therapies on the reproductive, productive, and economic efficiency of normal postpartum cows. To date, there are few studies dealing with the productive and economic effects of such therapies.

The reproductive performance of the group treated with GnRH was significantly improved when compared to untreated cows. Our results are supported by those of Fernandes et al ${ }^{16}$ who reported that GnRH accelerated the rate of uterine involution, suggesting that fertility indairy cows may be enhanced by improving the uterine environment more quickly postpartum. In addition, Nash et al. ${ }^{17}$ demonstrated that the administration of $250 \mu \mathrm{g} \mathrm{GnRH}$ at 14 days postpartum may induce early cyclic activity and subsequently improve fertility, giving a shorter interval from calving to conception, higher conception rate, and lower services per conception. Similarly, Peters and Bosu ${ }^{18}$ noticed that treatment with GnRH at 15 days postpartum may help cows that are free from puerperal infections. The interval from parturition to conception was significantly reduced, and improvement in some other reproductive parameters was observed in GnRH-treated cows between day 10 and day 12 postpartum Labib et al. ${ }^{19}$

Regarding the productivity of treated and untreated cows, ElTahawy and Fahmy $^{14}$ reported a positive impact on the milk yield of cows receiving GnRH. The increase in productivity of $\mathrm{GnRH}-$ treated cows reflected on the returns for these cows when compared to untreated ones.

The reproductive performance of cows treated with PGF2 alpha was not significantly different from that of untreated cows. Contrary to our data, Young et al. $^{20}$ reported that exogenous PGF2 alpha administered during the early postpartum period in cows from 14 to 28days might influence uterine involution and shorten the time for return to optimum fertility after calving, which significantly improves conception rate at first service. Moreover, Benmarad and Stevenson ${ }^{21}$ observed improvement in fertility in cows given PGF2 alpha (25mg lutalyse) between day 20 and 24 postpartum. They also found that the 
interval from calving to conception was decreased in all cows treated with PGF2 alpha, especially for cows with an abnormal puerperium. Further, services per conception were reduced in both normal and abnormal cows given PGF2 alpha. Improvement in fertility was associated with increased frequency and occurrence of ovulation and estrus before first service and the reestablishment of estrus cycles of normal duration before 6weeks postpartum. Heuwieser et al. ${ }^{22}$ reported that the strategic administration of PGF2 alpha to cows in the postpartum period increased efficiency of estrus detection and decreased the interval to first service and the number of days open. Elsheikh and Elzubeir ${ }^{7}$ showed that double injection of PGF2 alpha during the first week, single or double injection of PGF2 alpha during the second or third week postpartum minimized the days open and accelerated the uterine involution, therefore the use of PGF2 alpha during early postpartum period improved the reproductive efficiency of cross-bred dairy cows. Also, the same authors reported in their later work (2005) that reproductive efficiency of cross-bred dairy cows was improved when prostaglandin F2 alpha was injected during the first three weeks postpartum.

In agreement with our results, it was previously shown that the administration of PGF2 alpha or a combination of PGF2 alpha and prostaglandin (PG)E2 at 21 to 35days postpartum had no beneficial effect upon measured fertility variables, except for a tendency to shorten the interval from calving to first insemination. ${ }^{23}$ Another study reported a reduction in conception rate in primiparous cows after postpartum administration of PGF2 alpha, ${ }^{24}$ in agreement with our data.

Likewise, ergometrin-treated cows showed no improvement in their reproductive performance when compared to untreated cows. In contrast, it has been reported that injecting ergometrin directly after parturition indairy cows reduces the incidence of retained fetal membranes and improves reproductive performance. ${ }^{25}$ Similarly, Hussein \& Metwelly ${ }^{26}$ concluded that methyl ergometrin injection directly after parturition in dairy cows decreased the incidence of retained fetal membranes and improved the reproductive performance of treated cows compared to control. They also found that methyl ergometrin was superior to oxytocin.

Further, for oxytocin-treated cows, Metwelly \& EL-Bwab ${ }^{27}$ injected oxytocin directly after parturition in dairy cows and recorded a significant increase in reproductive performance (calving-estrus interval, days open, services per conception and total conception rate) in treated cows. Additionally, Hussein \& Metwelly ${ }^{26}$ showed that oxytocin injection directly after parturition in dairy cows decreased the incidence of retained fetal membranes and improved the reproductive performance. On the other hand, Convey et al. ${ }^{28}$ suggested that hormones released at suckling, such as oxytocin, may depress gona dotropin secretion and/or inhibit ovarian activity. Results obtained by Bajcsy et al., ${ }^{8}$ indicated that using oxytocin 50IU intramuscularly enhanced uterine contractility if treatment occurred on the first day postpartum data of another experiment revealed that oxytocin administration immediately after delivery reduced the occurrence of retained fetal membranes in cattle, subsequently reduced the incidence of endo metritis and improved the reproductive efficiency.

Foote \& Hunter ${ }^{29}$ supported the results of our study concerning estrogen treatment. They demonstrated that the postpartum interval was reduced in cows treated with estrogen as $10 \mathrm{mg}$ estradiol-17 $\beta$ compared to control animals. Similarly, Ulberg \& Lindley $^{30}$ and Saiduddin et al., ${ }^{31}$ reported that treatment of anestrous postpartum dairy cows with estrogen from 15 to 30 days postpartum tended to shorten the postpartum interval. In agreement with our data, ElTahawy \& Fahmy ${ }^{14}$ found that milk yield and returns parameters for estrogen-treated cows were greater than for untreated cows.

In order to attempt to achieve a more reliable response to oxytocin, estrogenic substances have also been given, in the hope of both increasing the sensitivity of the myometrium to oxytocin and enhancing the natural uterine defence mechanisms. ${ }^{32}$ For these reasons, the synthetic estrogens stilboestrol-dipropionate and estradiol mono benzoate have been widely applied to cows with retained fetal membranes in the form of parenteral injection or uterine infusion and pessary, and their use has sometimes been followed by injection of oxytocin.

In conclusion, the results of this study suggest that $\mathrm{GnRH}$ and estrogen are the best hormonal therapies and are more profitable than other treatments tested. They have a positive influence on the reproductive, productive, and economic efficiency of dairy cattle, increasing net returns and decreasing health costs.

\section{Acknowledgements}

None.

\section{Conflict of interest}

Author declares that there is no conflict of interest.

\section{References}

1. Grusenmeyer DC, Hillers JK. Evaluation the dairy herd's reproductive status fact sheet 1-9. In: Majeskie JL, editor. National Cooperative Dairy Herd Improvement Program Hand book. Columbs, Ohio, USA; 1989.

2. Ferguson JD, Galligan DT. Assessment of reproductive efficiency in dairy herds. Compend Contin Educ Proc Vet. 2000;22:5150-5158.

3. Foote RH, Rick PM. GnRH improves reproductive performance of dairy cows with slow involution of the reproductive tract. J Anim Sci. 1999;77(1):12-16.

4. Beckett SD, Lean IJ. GnRH in postpartum dairy cattle: a meta-analysis of effects on reproductive efficiency. Anim Reprod Sci. 1997;48(2):93-112.

5. Gaines J. The use of GnRH and PGF2 $\alpha$ FOR programmer breeding of dairy cattle. Prod Soc Theriogenology. 1994;109-119.

6. Manns JG, Richardson G. Induction of cyclic activity in the early postpartum dairy cow. Can J Anim Sci. 1976;56(3):467-473.

7. Elsheikh AS, Ahmed FO. Backing up postpartum dairy cows with PGF2 alpha. Journal of Animal and Veterinary Advances. 2005;4(5):506-509.

8. Bajcsy AC, Szenci O, van der Weijden GC, et al. The effect of a single oxytocin or carbetocin treatment on uterine Contractility in early dairy cows. Theriogenology. 2006;65(2): 400-414

9. Mollo A, Veronesi M, Cairoli F, et al. The use of oxytocin for the reduction of placental retention and subsequent endometritis. Anim Reprod Sci. 1997;48(1):47-51.

10. National Research Council. Nutrient requirements of dairy cattle. 6th ed. Natl Acad Sci. 1989

11. Arthur GH, Noakes DE, Pearson $\mathrm{H}$, et al. Infertility in the cow. In: Veterinary Reproduction and Obstetrics. 7 th ed. London: W.B. Saunders Publishers; 1998. p. 345-388.

12. Xu ZZ, Burton LJ, McDougall S, et al. Treatment of noncycling lactating dairy cows with progesterone and estradiol or with progesterone, $\mathrm{GnRH}$, PGF2a, and estradiol. J Dairy Sci. 2000;83(3):464-470. 
13. Sankhyan LP. Introduction to farm management. New Delhi: Tata McGraw-Hill publishing company limited; 1983.

14. El Tahawy AS, Fahmy MM. Partial budgeting assessment of the treatment of pyometra, follicular cysts and ovarian inactivity causing postpartum anoestrus in dairy cattle. Res Vet Sci. 2011;90(1):44-50.

15. SAS. Statistical Analysis System. Version 9.00. SAS Institute Inc., Cary, NC, USA; 2002.

16. Fernands LC, Thatcher WW, Wilcox CJ, et al. LH release in response to GnRH during the postpartum period of dairy cows. J Anim Sci. 1978;46(2):443-448.

17. Nash JG, Ball L, Olson JD. Effects on reproductive performance of administration of GnRH to early postpartum dairy cow. J Anim Sci. 1980;50(6):1017-1021

18. Peters AR, Bosu WT. Relationship of uterine infections and folliculogenesis in dairy cows during early puerperium. Theriogenology. 1988;30(6):1045-1051.

19. Labib F, El Azab MA, Sharawy SM. Effect of administration of gonadotropin releasing hormone during early postpartum period on reproductive performance of dairy cows. Assiut Vet Med J. 1988;20(39).

20. Young IM, Anderson BD, Plenderleith RW. Increased conception rates in dairy cows after early postpartum administration of prostaglandin F2 alpha. Vet Rec. 1984;115(17):429-431.

21. Benmarad M, Stevenson JS. Gonadotrophin-releasing hormone and prostaglandin F2 alpha for postpartum dairy cows: estrus, ovulation, and fertility traits. J Dairy Sci. 1986;69(3):800-811.

22. Heuwieser W, Tenhagen BA, Tischer M, et al. Effect of three programmes for treatment of endometritis on the reproductive performance of a dairy herd. Veterinary Record. 2000;146(12):338-341.

23. Hirsbrunner G, Burkhardt HW, Steiner A. Effect of a single administration of prostaglandin $\mathrm{F} 2 \alpha$, or a combination of prostaglandin F2 $\alpha$ and prostaglandin E, or placebo on fertility variables in dairy cows 3-5weeks postpartum, a randomized, double-blind clinical trial. Reprod Biol Endocrinol. 2006;4(65).
24. Mejia ME, Lacau Mengido IM. Endometritis treatment with a prostaglandin F2 $\alpha$ analog does not improve reproductive performance in a large dairy herd in Argentina. Theriogenology. 2005;63(5):1266-1276.

25. Eissa MS. Studies on postpartum ovarian dysfunction and their treatment in relation to reproductive performance in Friesian cows. Ph.D. Thesis, Fac Vet Med Alex Univ. 2003.

26. Hussein FM, Metwelly KK. Effect of methyl-ergometrine or oxytocin after birth on fetal membranes drop and reproductive performance in dairy cows. Alex J Vet. 2004;21(2):676.

27. Metwelly KK, EL Bwab LE. A study to improve the reproductive efficiency in postpartum cattle and buffaloes. Assiut Vet Med J. 1999;42(83):310-329.

28. Convey EM, Tucker HA, Short RE. Acute effect of suckling on gonadotropin, prolactin and glucocorticoid concentrations in serum of intact and ovariectomized beef cows. Theriogenology. 1983;20(6):661-674.

29. Foote WD, Hunter JE. Postpartum intervals of beef cows treated with progesterone and estrogen. J Anim Sci. 1964;23:517-520.

30. UIberg LC, Lindley CE. Use of progesterone and estrogen in the control of reproductive activities in beef cattle. J Anim Sci. 1960;19(4):1132-1142.

31. Saiduddin S, Quevedo MM, Foote WD. Response of beef cows to exogenous progesterone and estradiol at various stages postpartum. $J$ Anim Sci. 1968;27(4):1015-1020.

32. Arthur GH, Bee D. Veterinary Reproduction and Obstetrics. 7th ed. In: Arthur GH, Noakes DE, Pearson H, editors. London: W. B. Saunders, 1996. 